\title{
Hepatitis E Virus RNA Measurement
}

National Cancer Institute

\section{Source}

National Cancer Institute. Hepatitis E Virus RNA Measurement. NCI Thesaurus. Code C142331.

The determination of the amount of hepatitis E virus RNA present in a sample. 